\title{
Admittance Monitoring of Nonelectric Nature Objects
}

\author{
Tetiana Bubela, Petro Stolyarchuk, Yevhen Pohodylo, Marta Herasym
}

Institute of Computer Technologies, Automation and Metrology, "Lviv Polytechnic" National University UA

\begin{abstract}
Problems of development the methods of monitoring the quality indices of non-electric nature objects are in the highlight of the paper. The chain of experimental investigations of capacitance primary transducers in terms of their time stability (durability) and manufacturing material efficiency has been undertaken. The nature of frequency dependence of admittance on the temperature and different solution concentrations has been researched. Due to the results of investigations the method of identifying the general salt concentration in soil is proposed.
\end{abstract}

Keywords: double layer capacity, frequency dependence of active and reactive admittance components, nonelectrical objects, capacitance sensor

DOI: 10.14313/PAR_209-210/98

\section{Introduction, results of investigation}

Quality assessment of different nature and designation objects remain still a vital task for consumers and manufacturers. It is known that quality is characterized by the totality of quality indices, the most significant among them are treated to be the indices of chemical composition, since exactly they are crucial during stabilizing the properties of any object. Nowadays, the indices of chemical composition are controlled by labour-, time- and costconsuming physical and chemical methods $[1,2]$. Thus the problem of creating and evolving the methods free from the above mentioned disadvantages is of significance. An admittance method, one of the most promising, is based on the measurement of active $G$ (conductance) and reactive $B$ (susceptance) components of complex conductivity $Y[3,4]$.

Till the recent time, the subjects of the admittance method were the objects of non-electric nature, namely the elements of electric circuits (resistors, condensers, induction coils, etc.). The environmental objects (water and soils), products of food, light industries and other human activity areas which are non-traditional for admittance control, and represented by water solutions, belong to the objects of nonelectric nature.

So, there exists the problem of investigating the possibilities of the admittance method concerning the evalu- ation of quality indices of nonelectric nature objects, to solve which the following tasks have been formulated: to analyze the capacitance wire primary transducers in terms of the efficiency of the used material concerning its durability and sensitivity; to research the temperature dependence of admittance for water solutions; to single out the problems of monitoring the quality indices of such an object of nonelectric nature as soils are; to perform the research on electric properties of different water solutions following the admittance method, and due to the correspondent results to formulate the proposals concerning the usage of latter for the determination of a level of soil pollution (saltiness).

\section{Equipment and conditions of research}

Experiments were made on the basis of a LCR-meter using a primary transducer of a capacitance type (fig. 1).

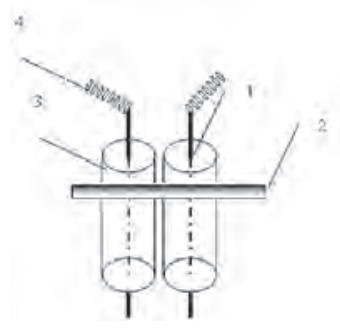

Fig. 1. The electrochemical cell with wire electrodes 1 - wire electrode, 2 - holder, 3 - glass tube, 4 - output for connecting to a device

Rys. 1. Komórka elektrochemiczna z elektrodami: 1 - elektroda; 2 - uchwyt; 3 - rura szklana; 4 - wyjście do połączenia $z$ urządzeniem

The range of the researched frequencies: $50 \mathrm{~Hz}-100 \mathrm{kHz}$. The level of a test signal: (0.01-2) V. The material of electrodes: platinum, copper and stainless steel. The distance between electrodes was varying within $(5-7) \mathrm{mm}$, the length of a working part made $(6-7) \mathrm{mm}$, its stability was provided by soldering the electrodes into chemically stable glass tubes. The objects of research were water solutions of different salts. The equivalent circuits for water solutions are presented in fig. 2 . 
a)

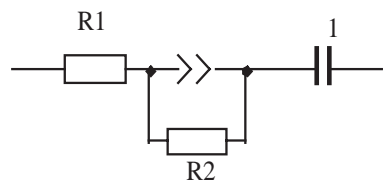

b)

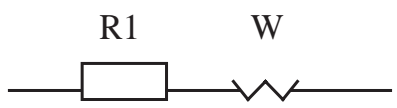

Fig. 2. The equivalent circuits for water solutions, where R1 is the resistance of the electrolyte, R2 is the resistance interfacial transition and $\mathrm{C} 1$ is the double layer capacity, $\mathrm{CPE}$ is the constant phase element, $\mathrm{W}$ is the element of Warburg: a) the range of the researched frequencies: $50 \mathrm{~Hz}-1 \mathrm{kHz}$; b) the range of the researched frequencies: $1 \mathrm{kHz}-100 \mathrm{kHz}$

Rys. 2. Schemat zastąpienia dla roztworów wodnych, gdzie R1 oznacza opór elektrolitu, R2 oznacza opór na granicy przejścia fazowego i $C 1$ jest pojemność warstwą podwójną, CPE oznacza element stałej fazy, W oznacza impedancję Warburga: a) zakres częstotliwości: $50 \mathrm{~Hz}-1 \mathrm{kHz}$; b) zakres częstotliwości: $1 \mathrm{kHz}-100 \mathrm{kHz}$

\section{Durability of transducers of the admittance of water solutions on type of materials}

The research concerning the repeatability of indices gained for the electrodes manufactured from different materials has shown that its extremum could be reached in the case of platinum electrodes and electrodes made from stainless steel (fig. 3a,b). It is explained by low chemical activity in the researched medium consisting of water solutions of different concentration salts.

In its turn, the durability is low for copper electrodes (fig. $3 \mathrm{c}, \mathrm{d}$ ) that is why the repeatability has not been reached. It is related to the high level of oxygenation of such electrodes at the interaction with the researched object even under the condition of their special maintenance.

\section{Primary transducer sensitivity with the different constant of an electrochemical cell}

While measuring the admittance of water solutions, the constant of an electrochemical cell depends on the ratio of the surface of sensor electrodes (sensitive sensor elements) to the distance between them. It has been proved that the rise in sensor sensitivity is proportional to that in an electrochemical cell constant. This is of special importance in the case of high-Ohm objects. a)

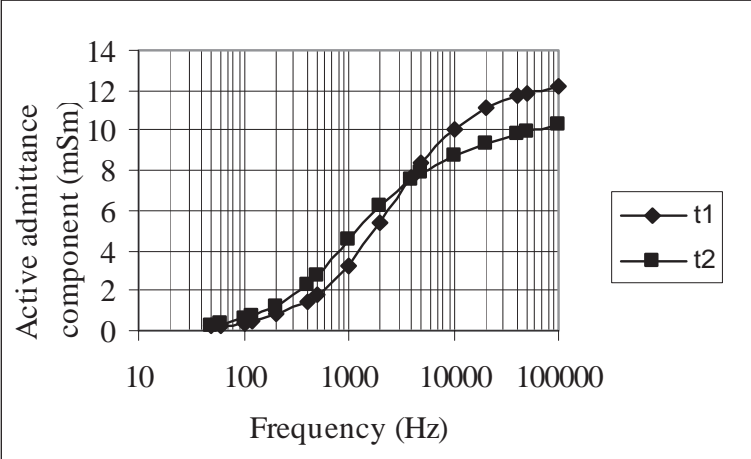

b)

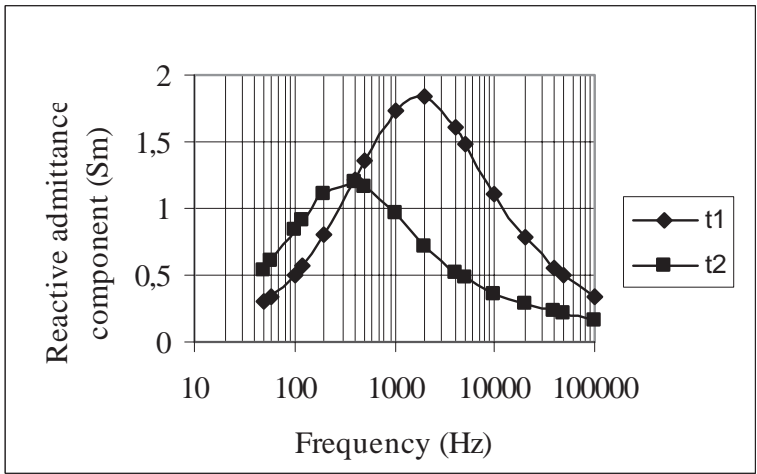

c)

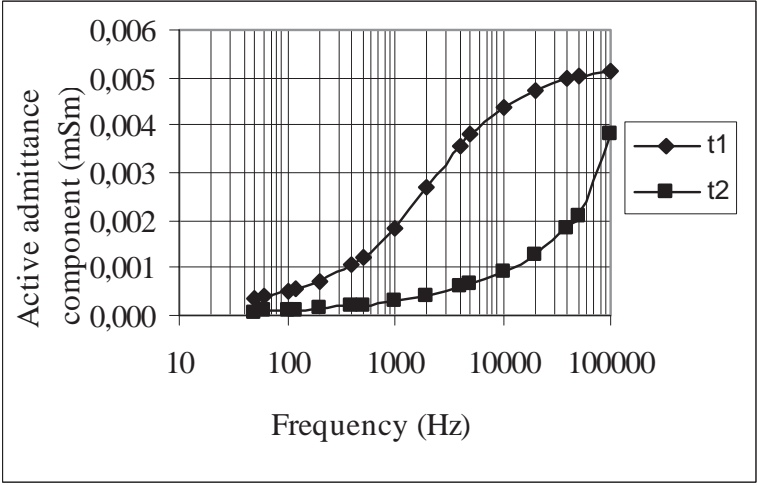

d)

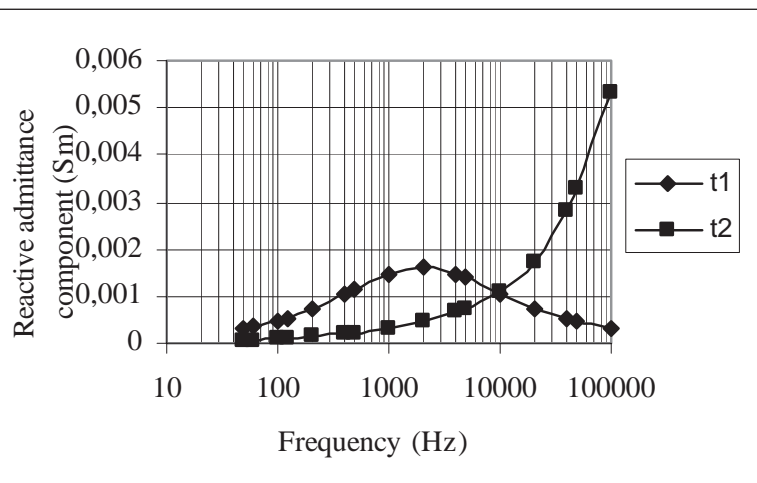

Fig. 3. Dependences of components of the admittance $Y=G+j B$ on frequency of sensor with platinum or copper electrodes in the $\mathrm{NaCl}$ solution (t1 initial measurement and t2 after 5 days): a), c) of an active component (conductance $G$ ); b), d) of a reactive component (susceptance $B$ )

Rys. 3. Zależności składowych admitancji czujnika z elektrodami platynowymi i miedzianymi od częstotliwości dla i roztworu $\mathrm{NaCl}$ (t1 pierwszy pomiar oraz t2 po 5 dniach: a), c) składowa aktywna (konduktancja G); b), d) składowa reaktywna (susceptancja $B$ ) 
a)

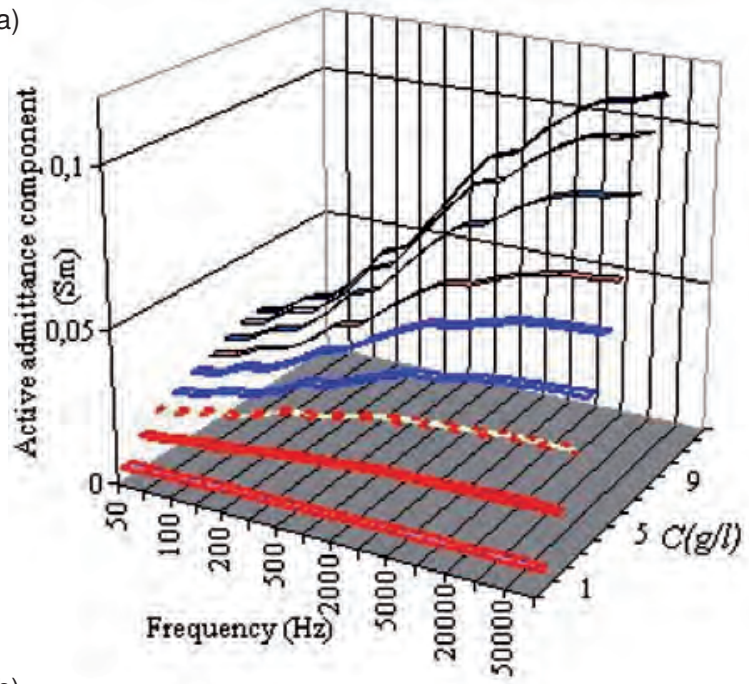

b)

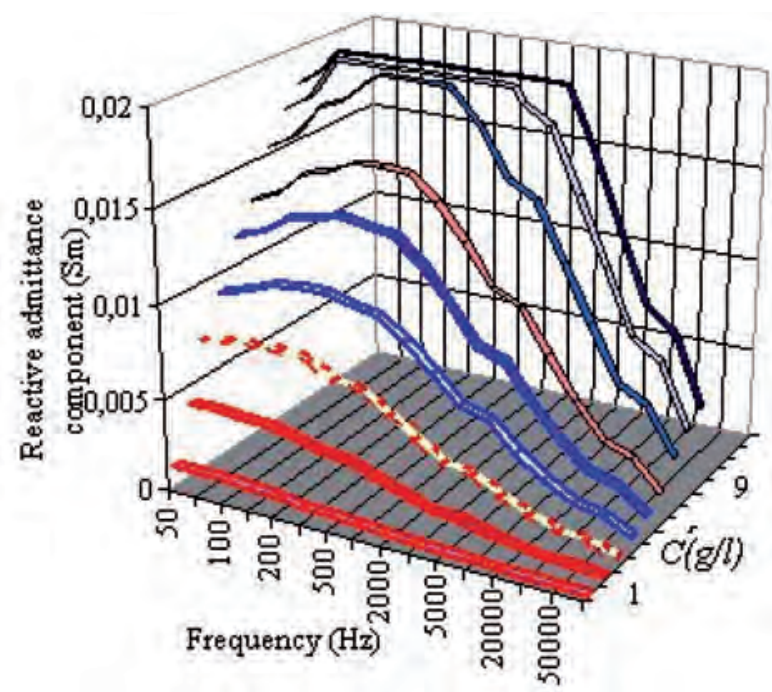

Fig. 4. Dependences of admittance components on frequency for different concentrations $C=(4-9) \mathrm{g} / \mathrm{l}$ of the $\mathrm{NaCl}$ solution: a) of an active component; b) of a reactive component

Rys. 4. Zależności składowych admitancji od częstotliwości dla różnych stężeń $C=(4-9) \mathrm{g} / \mathrm{l}$ roztworu $\mathrm{NaCl}$ : a) składowej aktywnej; b) składowej reaktywnej

Research on the admittance to frequency dependences of water solutions with different concentrations has been provided. The presence of the characteristic extremum for the reactive component $B$ (fig. $4 \mathrm{~b}$ ) revealing at certain frequency values was ascertained. For the active admittance component (fig. 4a) the extremum is not detected.

Besides, we should remark that the value of the frequency fmax at which the special extremum has been detected depends on the concentration, i.e. it rises with the increase in solution concentration. The similar phenomenon was observed also for other multi component solutions. This fact affirms the possibility to determine the general concentration of salt solutions not through the value of an active conductivity component that is an informative parameter for traditional conductometry [5] but rather through the value of frequency where the extremum of a reactive admittance component arises.

Obviously it is explained by the fact that the conductivity of solutions is caused by the presence of ions charge carriers. Their quantity affects both the increase of the absolute values of active and reactive admittance components, and the value of frequency at which the extremum of a reactive admittance component reveals.

The ascertainment of a new informative parameter for the quantity analysis of general solution concentration requires the further search for the advantages of this manner, particularly the research in terms of the sensitivity fmax to the alteration in the concentration $C$.

\section{Sensitivity of the frequency of extremum to changes of object concentration $\mathbf{S}\left(\mathbf{f}_{\max }\right)$}

The dependence of the frequency of extremum of reactive component of sensor admittance on the concentration $C$ of $\mathrm{NaCl}$ in water solution has been tested. It has been proved that this frequency could be approximated by the linear dependence with the high probability $\mathrm{R}^{2}=0.9967$ of approximation (fig. 5).

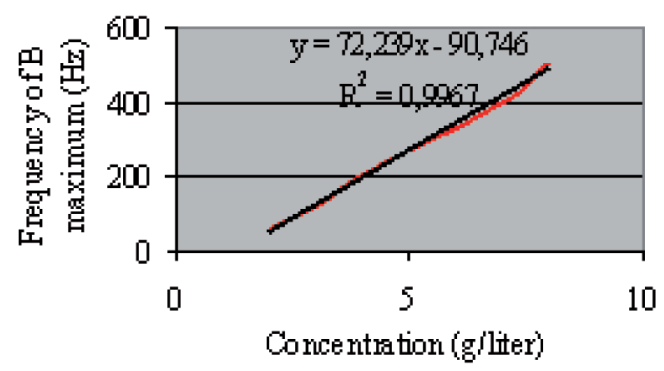

Fig. 5. Dependence of the frequency of extremum of reactive component $\mathrm{B}$ admittance $\mathrm{Y}$ on different concentrations $C$ of the $\mathrm{NaCl}$ solution

Rys. 5. Zależność częstotliwości ekstremum dla reaktywnej składowej $B$ admitancji $Y$ od stężeń $\mathrm{NaCl}$ w roztworze

Based on the constructed dependence (fig. 5), the sensitivity of the active conductivity component $S(G)$ has been calculated. The change in the concentration $C$ for $1 \%$ changed the active admittance component $G$ on $0.8 \%$. For $S\left(f_{\max }\right)$ the change in the concentration $C$ of $1 \%$ leads to $\Delta f_{\max }$ of $1.3 \%$.

$$
\frac{S\left(f_{\max }\right)}{S(G)}=1,6
$$

To wit, the sensitivity through the informative parameter fmax 1.6-fold exceeds the sensitivity through the 
active conductivity component which could be treated as a considerable advantage.

\section{Temperature dependence of the sensor admittance components for water solutions}

The tested objects are solutions, i.e. conductors of the second type. Their electric properties are affected by the temperature $T\left({ }^{\circ} \mathrm{C}\right)$. Then the following stage of experimental search is the research on temperature admittance dependence for water solutions of different chemical nature and concentrations. Particularly it has been ascertained that the absolute values of active and reactive components depend on the temperature. Moreover, the active component depends to a greater extent (fig. 6a) then reactive one. However, the frequency values of the reactive admittance component extremum

a)

\section{A ctive admittance} component (Sm)

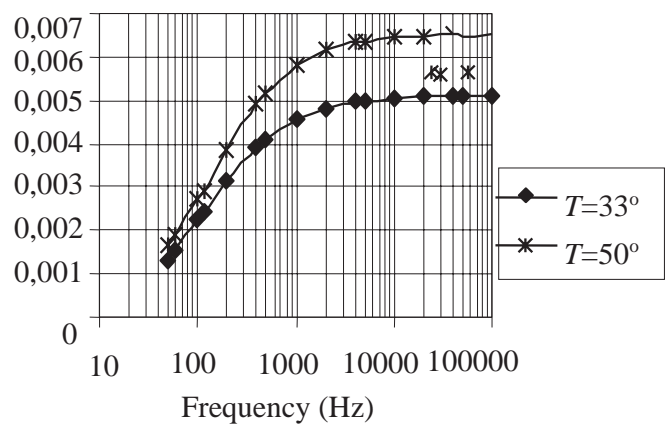

b)

\section{R eactive admittance} component (Sm)

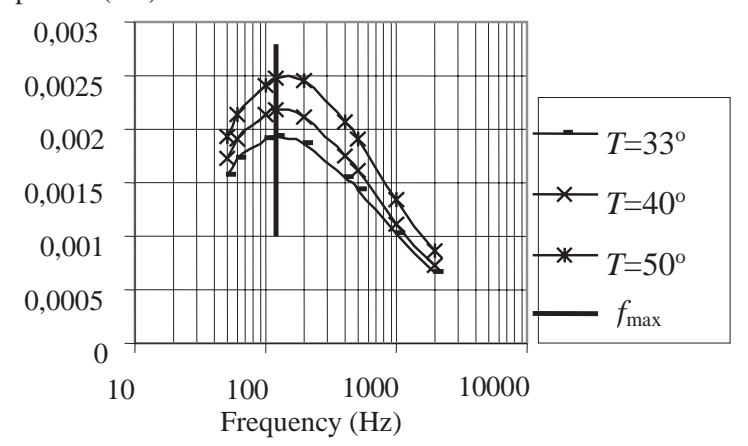

Fig. 6. Frequency dependence of admittance $Y=G+j B$ components to the temperature of the $\mathrm{NaCl}$ solution sensor with platinum electrodes: a) for an active component of admittance (conductance $G$ ); b) for a reactive admittance component (susceptance $B$ )

Rys. 6. Częstotliwościowa zależność admitancji $Y=G+j B$ od temperatury $T$ czujnika z elektrodami platynowymi dla roztworu NaCl: a) dla aktywnej składowej admitancji (konduktancja $G$ ): b) dla składowej reaktywnej - susceptancja $B$ $f_{\max }$ are invariant to the alteration in temperature and are placed on one vertical straight line (fig. 6b). This fact is a testimony of one more advantage, present at the choice of the frequency of extremum of the reactive conductivity component as an informative parameter while determining the general concentration of salts in a solution.

\section{Method of determining of the general concentration of salts}

The monitoring of salt and humidity [6-8] content in solutions is extremely important for the environmental objects, especially in the case of soils. Soil solution is the most active part of soil that is a direct source of nutriments for plants. Its concentration is changing consequently of different biological, chemical and physicochemical processes.

The salt incoming into soil solution depends on the processes of mineral efflorescence and destruction, application of organic manure and fertilizers as well as other factors.

So the concentration of soil solution of non-salted soils is rather small and varies within the limits from tenths of a gram to several grams of substance per a litre. In the case of salted soils, the content of dissolved substances reaches the tens and sometimes even hundreds per a litre. The surplus of water-soluble salts in the soil (more than $0.2 \%$ or $2 \mathrm{~g}$ per $1 \mathrm{~kg}$ of soil) harmfully influences plants, at salt content of $(0.3-0.5) \%$ plants perish. The most dangerous salts for soils are chlorides and sulfates that is why the subjects of research are the following salts $\mathrm{NaCl}$, $\mathrm{KCl}, \mathrm{CuSO}_{4}$.

As was mentioned before, in the traditional way of determining the content of salts in solutions, an informative parameter is electro-conductivity which is proportional to concentration [5]. However, since electro conductivity of a solution considerably depends on temperature, this way implies the measurement of both electroconductivity and temperature for temperature error correction.

In addition, the informative electro-conductivity, proportional to the salt content, is also influenced by the non-informative conductivities caused by the parameters of a sensor and its connection to the measurement means (near-electrode effects etc.). To reduce such influence, we should provide the special measurement conditions or more sophisticated measuring means during this method realization. To wit, the known method does not provide the invariance of a result to influencing factors.

Thus there has appeared the task of evolving this method of salt content determination in solutions, which realization would provide the invariance of a result to the outer influencing factors, in general leading to the efficiency of monitoring, particularly in identifying the content of salts that cause the hardness of water, and general concentration of salts dissolved in water remaining in soil. The established task is suggested to be solved by the application of the method identifying the general salt concentration at which the frequency of reactive admittance component extremums would take the part of an informative parameter. 


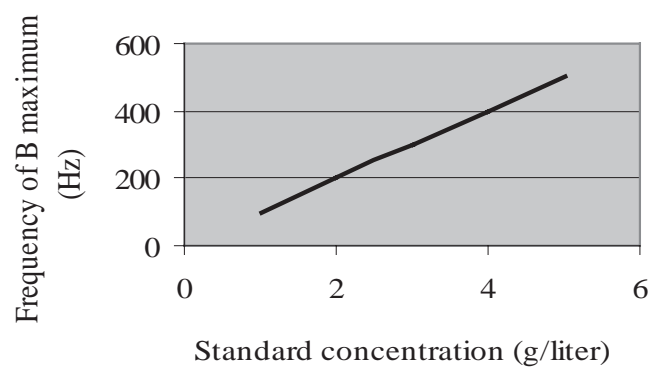

Fig. 7. Calibrating curve of frequency extremes of the reactive admittance component as function of the known concentrations $C$ of standard solutions

Rys. 7. Krzywa kalibracji zmian częstotliwości ekstremum reaktywnej składowej admitancji jako funkcji znanych wzorcowych wartości stężeń $C$

The method could be realized as follows:

- to determine the electro conductivity of a solution under the influence of a test signal of alternating current,

- to ascertain the calibrating dependences "the frequency of the reactive admittance component extremum concentration" for the standard solutions with the known concentrations (fig. 7),

- to record the extreme value of a reactive conductivity component of the researched solution, altering the frequency of a test signal determined for the correspondent frequency value,

- to compare to the calibrating dependences,

- to determine the content of salts in the researched object.

For example, to determine the hardness of water in this way, we should construct the dependence of frequency on the extreme value of a reactive component for the patterns of different hardness due to the appropriate standard patterns. This dependence should be constructed for the salt content in different solutions, e.g. for the content of sulfates and phosphates in soil solutions in order to conduct the agrochemical and meliorating monitoring of lands, control of a salt mode of soils and waters $[9,10]$.

\section{Uncertainty sources of the proposed method}

Uncertainty of results [11] of the proposed method includes the uncertainties of its realization stages, namely:

- preparing the object for the analysis;

- preparing standard solutions;

- calibration procedure;

- determining the frequency at which the extremum of the admittance reactive component of the researched object occurs.

At the first stage of preparing the object for the analysis, the uncertainty could be caused by incorrect preparing of a soil salt extract. At the stage of preparing standard solutions, the uncertainty is related to ascertaining the concentration of standard solutions. In physical and chemical analysis, the concentration of a mineral element in the solution could be calculated according to the expression:

$$
C=\frac{\mu \cdot N}{V},
$$

where: $C$ is the concentration of a mineral element in the solution, $\mu$ is the mass portion of a main substance, $N$ is the value of substance amount in a batch (mol), $V$ is the volume of a measuring phial.

The total standard uncertainty of preparing the concentration $C$ of a mineral element should be calculated according to the expression:

$$
U^{2}(C)=\sqrt{\sum_{i=1}^{n}\left(\frac{\partial C}{\partial x_{i}}\right)^{2} \cdot U^{2}\left(x_{i}\right)},
$$

where $U^{2}(C)$ - total standard uncertainty of a mineral element concentration, $\frac{\partial C}{\partial x_{i}}-$ coefficients of function arguments' influence on the function value, $U^{2}\left(x_{i}\right)-$ standard uncertainties of function arguments.

From (2) and (3) expression of $U^{2}(C)$ can be written in the following form:

$U^{2}(C)=\left(\frac{\mu}{V}\right)^{2} \cdot U^{2}(N)+\left(\frac{N}{V}\right) \cdot U^{2}(\mu)+\left(\frac{-\mu \cdot N}{V^{2}}\right)^{2} \cdot U^{2}(V)$

where $\left(\frac{\mu}{V}\right),\left(\frac{N}{V}\right),\left(\frac{-\mu \cdot N}{V^{2}}\right)^{2}$ are the coefficients of influence of arguments $N, \mu, V$ on the function value $C, U^{2}(N)$, $U^{2}(\mu), U^{2}(V)$ are the standard uncertainties of $C$ function arguments, calculated on the basis of inquiry data of the $B$ type.

The procedure of calibrating and determining the frequency of the extremum of the reactive component of admittance of tested object depends on the instrumental uncertainties of the frequency meter.

Combined standard uncertainty $u_{C}$ and expanded uncertainty $U$ of results of the proposed method was calculated:

$$
u_{C}=1.7 \% ; U=u_{C} \cdot k_{0.95}=2.8 \%
$$

where $k$ is the coverage factor.

\section{Impact of double layer capacity on the measurement result}

A large increase of requirements to products quality gives an impulse to the permanent search of new methods and measuring instruments. For today, application of electric methods of quality monitoring of nonelectric nature objects through measuring of their electrophyics parameters have suffered an extensive use. Predefined it by simplicity of practical realization, operationability and 
availability of appropriate measuring instruments. Complexity of the problem in this case is that to measure a dielectric and magnetic permeability, electrical resistance and other parameters it is necessary to pass an electric current through the monitored object. At implementation of any measurement on an alternating current is needed to pay attention on: frequency of measuring signal, non-linearity of electrochemical processes, forming of erroneous effects as a result of disturbance of the measuring modes, random electric interferences from industrial frequency, that is also able to create problems. Thus, flowing of electric current is accompanied by many side processes and phenomena. These features appear near the electrodes of sensors [12]. In particular, at the surfaces of the electrodes always create double charged layers, occurs heating of near-electrode layers and a variety of other events are happening.

It is known that the near-electrode effects (including double layer capacity) have the most significant influence on the results of measurements of electrophysical parameters of liquids and friable materials with using contact transducers. The capacity of double layer is determined by the inductivity of monitored object (any substance or material), by an area of electrodes, by the distance between them, etc. The research of double layer capacity influence on active and reactive components of impedance and admittance on the whole shows that from the depending of test signal frequency range, which operate on a primary transducer, it is possible to choose a that or other informing parameter. The informing parameters of imittance is active resistance, active or reactive components, tangent of losses corner. As, a variation range of informing parameters can be very wide (from Ohm units to hundred of $\mathrm{Ohm}$ ), then actual is an analysis of double layer capacity influence on the result of such objects measurement. The anymore, that a variation range of double layer capacity can be in limits from tenth $\mu \mathrm{F}$ to hundred $\mu \mathrm{F}$, and here capacity that is determined by sensor parameters and monit,ored object is in limits from units to hundred $\mathrm{pF}$.

In practice, the contact measuring cells are widely used, a galvanic contact between the electrodes can bring to the different errors of measurement, that unite under the general name of electrode polarization. Material of electrodes can finally influence on character of measuring cell polarization. Mostly for the electrodes of cells are used the next materials: platinum; steel covered by inorganic carbides; sintered coal; stainless steel. The basic disadvantage of these primary transducers is influence of complex resistances of double layers on the results of measurement. In addition, there is a non-linearity of the primary measuring transducers, which caused by a change of double layer capacity from the magnitude of the current flowing through it [13].

Formation of double layer capacity has a significant impact on speed of electrode processes, firmness of the dispersible systems, adsorption of ions and neutral molecules, wettableness, coefficient of friction and other properties of interfacial borders. In many cases a double electric layer has a difficult structure, but most detail of his appearance is studied on the border of division between a metallic electrode and solution of electrolyte.

There are different reasons of formations of double electric layer, basic from them numerated below:

- Nascence of double layer as a result of superficial dissociation.

- The double electric layer can appear as a result of selective adsorption of one of electrolyte ions that is contained in solution, due to superficial dissociation of functional groups or orientation of arctic molecules on a interfacial border.

- And another method of formation of double layer is an arctic molecules orientation on a interfacial border. Through complication of processes that take place on electrodes, and by difficulties of their control during realization of measuring, there are a few possibilities of reduction of double layer influence:

1. The first from that is a contactless conductometry. Measurement conducts with application of capacity $(-)$ or inductive $(\mathrm{L}-)$ cells. Applications of capacity cells use for measuring of low conductivity, and inductive - for high conductivity. Inductive cells based on principle of electromagnetic induction, in that a measuring sensitiveness rises with the increase of sample volume. It is necessary to notice that basic advantage of contactless conductometry is a high sensitiveness. For lack of contact electode material with an investigated environment disappear any errors related to the polarization of the electrodes, and contactless methods can be used during measurements in harsh environments. The disadvantage of this method is the inability to determine the different types of ions.

2. Increase of frequency source (high-frequency measurement). At measuring of conductivity with the help of double-electrode conductometry cell on high-frequencies it is possible to remove many indeterminant parameters, however an error will remain from polarization of electrodes. In addition a high-frequency test signal not always can be used, it can lead to the change of some properties of products and to its spoilage. Such changes can be considered as a methodical error. Therefore, the lower level of the test signal, the less methodical error of evaluation quality.

3. Other possibility of the measuring error component reduction is the implementation of the four electrode primary transducer, which is recently widely used in measurements of the conductivity. It contains two external and two internal electrodes. In this structure the influence of unstable characteristics of the double electrical layers is significantly reduced (fig. 8).

4. Application of schematic instruments, that gives an opportunity to create on the monitored object a given current mode at measuring of impedance or preset voltage mode at measuring of admittance, that simplifies a realization of measuring highway from treatment of initial voltage of transducer. At the same time, the parameters of separate objects exactly depend on the set mode of measurement. 


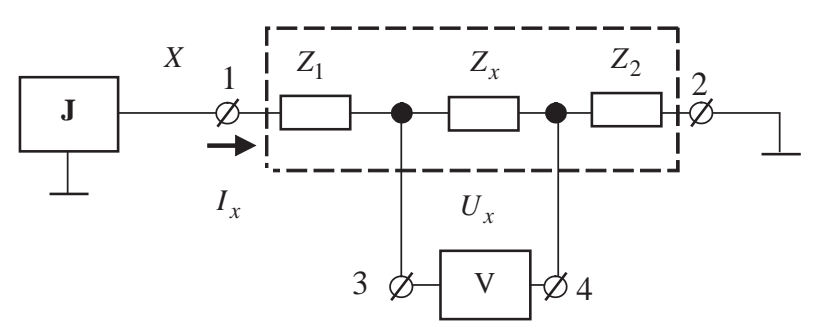

Fig. 8. Transducer of admittance parameters of the four-contact sensor into voltage $U_{x}$

Rys. 8. Przetwornik parametrów admitancji czterozaciskowego czujnika na napięcie $U_{x}$

5. To reduce the impact of near-electrode effects need to: wash the sensor before measurements, use the special connection, follow the cell constant volume and fixed orientation of the sensor in the vessel with the liquid.

Many objects of nonelectric nature today are presented by different electric models, however it is necessary to specify the frequency range of test signal, as influence of every element of electric model on different frequencies is different. After the analysis of mathematical models of electric schemes in a wide frequency range it is possible to define optimal ranges of frequencies measurements in which measuring of informing parameters is simplified, to detect characteristic features of dependences immitance components from frequency.

Return to four electrode sensor, as this construction is most widespread. Four electrode sensor consists of two internal (potential) and two external electrodes. By means of internal electrodes a voltage drop is formed on part of monitored object that answers a distance between them. And also, introduction of two potential electrodes leads to an occurrence of double layer capacities, however substantial reduction of their influence in comparing to other indeterminate parameters is possible by a way of area reductions of corresponding electrodes.

The invariance of measuring result is provided to the indeterminate parameters by measuring the voltage $U_{x}$ on potential electrodes at a given current $I_{x}$ through the monitored object between external electrodes. The measured voltage at a certain current will be proportional to the impedance $Z_{x}$ of the monitored object, as follows [14]:

$$
U_{x}=I_{x} Z_{x}
$$

The following expression can realize by connection of sensor with control object to the current source $\mathbf{J}$ and measuring the components of voltage $U_{X}$ with a special voltmeter $V$ sensitive to its phase.

For realization of given current mode it is necessary to have an AC current source $\mathbf{J}$ to give the known current $I_{x}$ of controlled frequency $f$ and device measuring the AC voltage component $\operatorname{Im}\left[U_{x}(f)\right]$. For providing of result invariance to influence of voltage measuring device the last must have high entrance resistance on frequencies of the chosen measuring frequency range. Taking into account, the result of impedance measuring will depend on stability of current $I_{x}$ through an object, that it is no simple to provide such stability in a wide frequency range.

An alternative method to above described with $\mathrm{AC}$ automatic bridge is possible also to use [17].

The measuring passive and active components of ad-mittance of the nonelectric objects with four electrode contact sensors can be used as indicators monitoring the quality of products. These transducers are provide the invariance of the measuring result to the double layer capacity and to parameters of the test signal [15].

Thus, near-electrode effects, in particular a double layer capacity is a basic impact factor on the result of measurement. Removing him is possible by the choice of test signal frequency, measuring mode, the compliance of measurement conditions, usage of contactless conductometry, and also a choice of sensor construction.

\section{Conclusions}

The results of experiments have proved that the best reputation belongs to the electrochemical cells with platinum electrodes and stainless steel electrodes, since they are chemically stable to the outer influences and have the durable characteristics.

The results of admittance frequency dependence researches on the temperature and different solution concentrations have allowed to find the extremum of frequency of reactive admittance component as an informative parameter of identifying the general salt concentration in a solution.

Due to the results of our research, the method of identifying the general salt concentration in solutions (soil solutions), and hence a new method of physicochemical analysis in which the frequency of an altering signal is treated as an informative parameter have been proposed. The advantages are well stipulated, the main among them are the invariance of an informative signal to the changes in temperature, and assurance of higher sensitivity as compared to traditional methods.

The most significant influence on the results of measurements of electrophysical parameters has the nearelectrode effects. The possibilities of reduction of double layer influence are considered.

\section{Bibliography}

1. ISO 10382:2002 Soil quality - Determination of organochlorine pesticides and polychlorinated biphenyls - Gaschromatographic method with electron capture detection.

2. Hignett, C. et al., Methods of Soil Analysis. Part 4 Physical Methods, 2009.

3. Hee-Won Shin et al., Pneumatochemical Immittance Spectroscopy for Hydrogen Storage Kinetics, "J. Phys. Chem." 117(39)/2013, 19786-19808. 
4. Mikhalieva M. et al., Qualitative and quantitative research on pesticide chemical admixture in liquids, in Proceedings of the Conference on 'Intelligent Data Acquisition and Advanced Computing System: Technology and Applications (IDAACS 2013)', Berlin, 12-14 September 2013, 82-85.

5. ISO 11265:1994. Soil quality. Determination of the specific electrical conductivity.

6. Baumhardt R.L. et al., Soil material, temperature, and salinity effects on calibration of multisensor capacitance probes, "Soil Sci. Soc. Amer. J. " 64/2000, 1940-1946.

7. Evett, S.R. et al., Soil profile water content determination: Sensor accuracy, axial response, calibration, temperature dependence and precision, "Vadose Zone J." 5/2006, 894-907.

8. Bogena H. et al., Evaluation of a low-cost soil water con-tent sensor for wireless network applications, "Journal of Hydrology" 344/2007, 32-42.

9. Bubela T. et al., Admittance Method Application in the Maintenance of Eco-monitoring Information System for Soil Parameters, Proceedings of the Conference on 'Intelligent Data Acquision and Advanced Computing System: Technology and Applications (IDAACS 2011)', Prague, Czech Republic, 15-17 September 2011, 97-100.

10. Pokhodylo Y. et al., Express-Method for Liquid Quality Level Monitoring in Proceeding of the 5th IEEE International Workshop on Intelligent Data Acquisition and Advanced Computing Systems: Technology and Applications, Rende (Cosenza), Italy, 21-23 September 2009, 87-89.

11. Guide to the Expression of Uncertainty in Measurement: First edition, ISO, Switzerland 1993.

12. Bakshi A.V., Bakshi U.A., Instrumentatio, Technical Publications, India 2009.

13. Méndez A. et al., Thermodynamic Study of PEG ( $M W$ 20,000) Adsorption in the Presence of Cl-Anions onto a Polycrystalline Gold Electrode, "J. Electrochem. Soc." 159(3)/2012, 48-55.

14. Alan S., Measurement and Instrumentation Principles, Butterworth-Heinemann 2001.

15. Stolyarcuk P. et al., Electric Sensors for Express-Method Checking of Liquid Quality Level Monitoring, "Sensors \& Transducers Journal" 8/2010, 88-98.

16. Moroń Zb., Pomiary przewodności elektrycznej cieczy przy matych częstotliwościach. Oficyna Wydawnicza Politechniki Wrocławskiej, Wrocław 2003.

17. Surdu M.N., Lameko A.L., Labuzov A.E., Journal: Measurement Techniques - Izm. Tech., engl trans. Springer, Vol. 53, No. 9, 2010 1055-105.

\section{Monitorowanie admitancji obiektów nieelektrycznych}

Streszczenie: W pracy przedstawiono propozycję udoskonalenia metod monitorowania parametrów jakości obiektów o charakterze nieelektrycznym. Zbadano stabilność czasową i wpływ rodzaju materiału elektrod na parametry przetworników pojemnościowych oraz częstotliwościowe zależności składowych admitancji od temperatury i stężenia roztworów. Zaproponowany sposób określenia całkowitego stężenia soli w glebie.

Słowa kluczowe: pojemność warstwy podwójnej, zależność częstotliwościowa aktywnej i reaktywnej składowej admitancji, sposób monitorowania parametrów elektrycznych, obiekty o charakterze nieelektrycznym, czujnik pojemnościowy

Artykuł recenzowany, nadesłany 11.03.2014 r., przyjęty do druku 24.06.2014 r.

assoc. prof. Tetiana Bubela PhD

Education: Graduate Diploma in Information and Measuring Technique. Professional interests: Practical research efforts are being steered towards the evolution of metrological technique for measuring the production quality characteristics. Author of over 90 scientific papers.

e-mail:paholuk@ukr.net

prof. Petro Stolyarchuk PhD El. Eng. Education: Graduate Diploma in Electric Engineering. Professional interests: Theoretical searches root in the extension of basic principles for the scientific technical standardization of production and service characteristics as well as their assessment aimed at increasing the competitive ability of national production. Author of over 350 scientific papers.

e-mail: stolyarchuk@polynet.Iviv.ua

prof. Yevhen Pohodylo PhD El. Eng. Education: Graduate Diploma in Electric Engineering. Professional interests: Methods and instruments for measuring immitance objects of electrical and nonelectrical nature; quality control of qualimetry objects by electrical parameters; parametric transducers. Author of over 200 scientific papers.

e-mail:pokhodylo@lp.edu.ua

\section{Marta Herasym, postgraduate}

Education: Graduate Diploma in quality, standardization and certification. Professional interests: Monitoring of electrophysical parameters of nonelectric products (liquids, granular materials) by means of primary capacitive transducers. Author of over 20 scientific papers.

e-mail:marta88leskiv@gmail.com
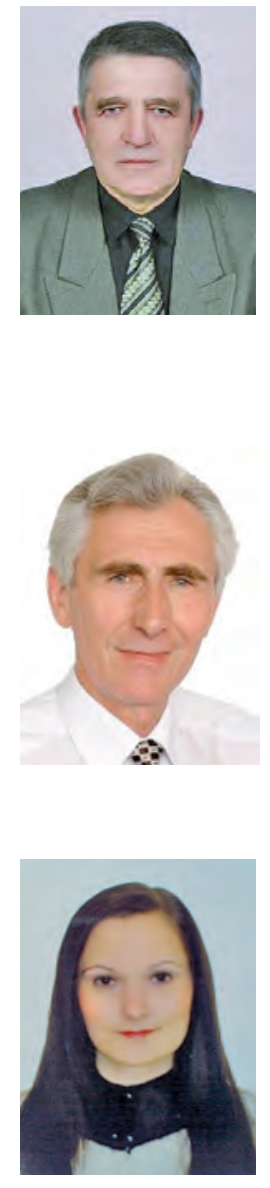